DOI: 10.17707/AgricultForest.62.1.15

\author{
Vasilije ISAJEV, Sasa ORLOVIC, \\ Milena STANKOVIC, Stefan STJEPANOVIC ${ }^{1}$
}

\title{
VARIABILITY IN THE CONCENTRATION OF TOTAL PROTEINS AND ACTIVITIES OF PEROXIDASE ENZYME IN TWO-YEAR-OLD NEEDLES OF AUSTRIAN PINE (Pinus nigra Arnold)
}

\begin{abstract}
SUMMARY
Variability in the concentration of total proteins and activities of peroxides enzyme in two-year-old needles of Austrian pine (Pinus nigra Arnold), were studied in the needles of eight different half-sib lines of Austrian pine. The samples were taken from a twenty-two-year-old seedling seed orchard on Jelova Gora (Western Serbia). The results of this study show the pronounced variability of the concentration of total proteins, and enzyme activity of peroxides in the study half-sib lines. This infers that proteins have different levels of expression in individual Austrian pine lines. Also the enzyme of peroxides shows different activity depending on the genetic constitution of the trees of the analyzed half-sib lines. Based on the seed orchard size and the planting pattern, it can be assumed that the effect of external factors is reduced to a minimum. The peroxides present as soluble in the apoplast or with covalent bond to cell wall, have an important role in lignification, suberisation, healing of injuries, defense against pathogens and atmospheric pollutants.
\end{abstract}

Keywords: peroxides enzyme, proteins, needles, Austrian pine

\section{INTRODUCTION}

The influence of genetic variability on some enzymes and the occurrence of isoenzymes which are specific for some varieties of plant species have been known from earlier studies (Schmidtling \& Hipkins, 1998; Leinemann, 2000). Question is still posed how great the influence of genetic diversity is on these biomacromolecules in comparison with the effect of various environmental factors. In order to familiarize with the effect of genetic potential and diversity on one of the key enzymes involved in the stress response, which is also responsible for lignification process in cell wall, enzyme activity of peroxidases was monitored in the needles of Austrian pine (Pinus nigra Arnold) half-sib lines. Genetic diversity causes various expression and reactivity of the enzyme, as well

\footnotetext{
${ }^{1}$ Vasilije Isajev, (corresponding author: dule78@ hotmail.com), Faculty of Forestry, University of Belgrade, SERBIA, Faculty of Agriculture - Department for Forestry, University of East Sarajevo, BOSNIA AND HERZEGOVINA, Sasa Orlovic, Institute of Lowland Forestry and Environment, University of Novi Sad, SERBIA, Milena Stankovic, Stefan Stjepanovic, Faculty of Agriculture Department for Forestry, University of East Sarajevo, BOSNIA AND HERZEGOVINA

Paper presented at the $6^{\text {th }}$ International Scientific Agricultural Symposium "AGROSYM 2015".

Notes: The authors declare that they have no conflicts of interest. Authorship Form signed online.
} 
as various isoenzyme forms. In addition, activity of this enzyme in dependence on medium acidity was monitored. By means of isoelectrofocusing, isoenzymes were determined which participate in the mentioned reactions and processes in eight selected Austrian pine lines incorporated in generative seed orchard.

Generative seed orchard of Austrian pine on Jelova Gora mountain has metapopulation structure and area of 3.10 ha. It was established with 40 half-sib lines of Austrian pine, with the total of 5700 plants. On the basis of relatively small orchard area, it can be assumed that environmental factors are more or less uniform, whereby almost the same conditions for the growth and development of the trees of all half-sib lines are provided. Therefore, the results obtained from the analyses which were carried out to the greatest extent reflect the influence of genetic diversity of the half sib lines.

In two-year-old needles, the activity of soluble peroxidases (POD) present in cytoplasm and apoplast was measured, as well as the concentration of total proteins in both fractions. In addition to enzyme activity, isoenzyme profile on polyacrylamide gel was also monitored.

\section{MATERIAL AND METHODS}

Experiments were done on two-year-old needles of Austrian pine (Pinus nigra). Needles were taken from ten-year-old Austrian pine trees. Material was frozen and transported to laboratory where the analyses were performed. Samples for the extraction of enzymes were homogenized, $1 \mathrm{~g}$ each. Activities of peroxidase enzyme were analyzed. Isoenzyme profile of this enzyme was determined in soluble fraction. In addition, the concentration of total proteins was determined. Concentration of proteins was determined with the use of Bradford (Bradford, 1976) method. This method is based on binding Coomassie Brilliant Blue G 250 to aromatic amino acid residue, whereby maximum color absorption is moved from $465 \mathrm{~nm}$ to $595 \mathrm{~nm}$. The color is developed after 2 min and the increase of absorbance is measured at $595 \mathrm{~nm}$.

\section{RESULTS AND DISCUSSION}

Genetic diversity causes various expression and reactivity of the enzyme, as well as a variety of isoenzyme forms. In order to obtain an answer to the question how large the effect of genetic diversity is on one of the key enzymes involved in the stress response, which is also responsible for the process of lignification in cell wall, the enzyme activity of peroxidases was monitored. In addition, activity of this enzyme in dependence on medium acidity was monitored. By means of isoelectrofocusing, isoenzymes were determined which participate in physiology processes in the needles of the tested Austrian pine lines.

Specific enzyme activity of peroxidases was first tested with regard to different $\mathrm{pH}$ values of medium, i. e. buffer on which the reaction was measured. In that way, optimum $\mathrm{pH}$ value was precisely determined for the enzyme reaction of total peroxidases in the needles of Austrian pine. It was determined that 
optimum value of $\mathrm{pH}$ is 5.5 for peroxidase reaction (Figure 1). Reaction was performed in the mixture of isocitrate-phosphate buffers with various $\mathrm{pH}$ values $(3-8)$. PH optimum of the reaction is the same as for peroxidases isolated from spruce needles.

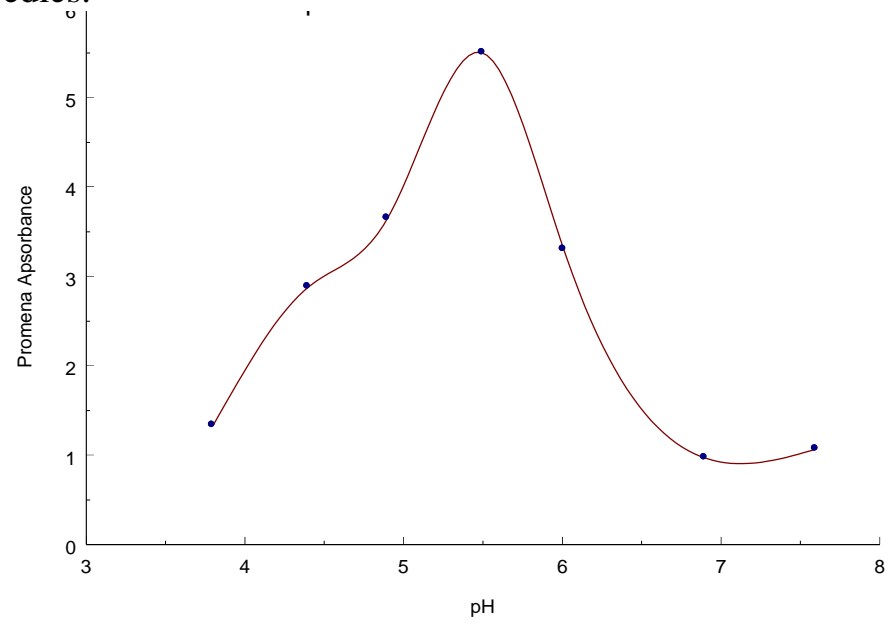

Figure 1. Optimum $\mathrm{pH}$ value for the enzyme reaction of total peroxidases from the needles of Austrian pine

Figure 2 shows the concentration of total proteins in the isolate of austrian pine needles. Protein content in different lines ranges from 0.05 to $0.20 \mathrm{mg} / \mathrm{ml}$. The lowest protein content was measured in the needles of the line 23, and the highest in the line 32 . In the figure, statistically significant differences among the lines are marked. Statistically, the lines 23 and 40 differ from the other lines to the greatest extent. Synthesis of total proteins depends on many factors (external and internal).

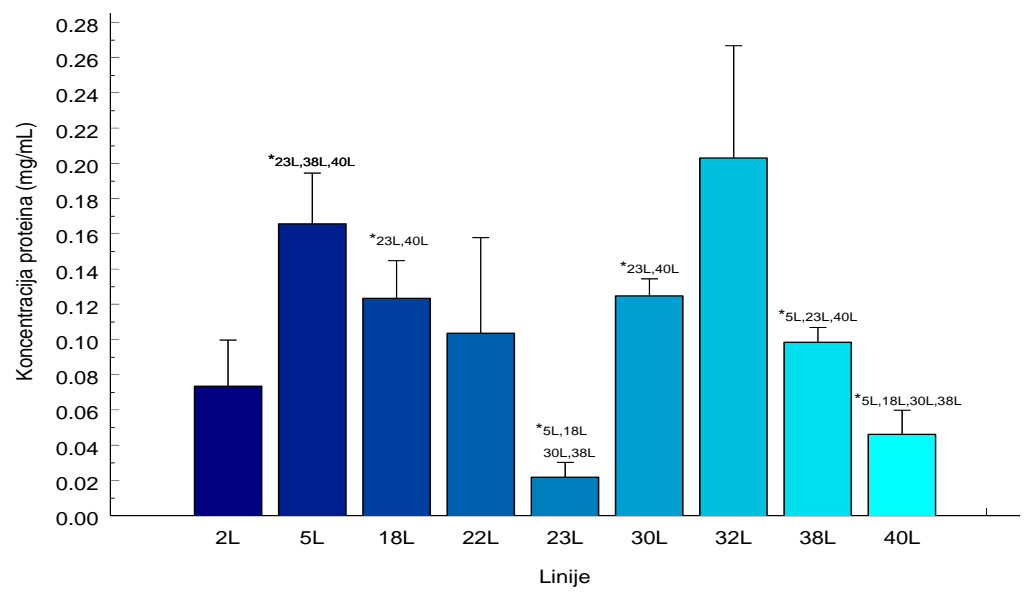

Figure 2. Concentration of proteins in the needles of various Austrian pine lines.expressed in $\mathrm{mg}$ per $\mathrm{ml}$ 


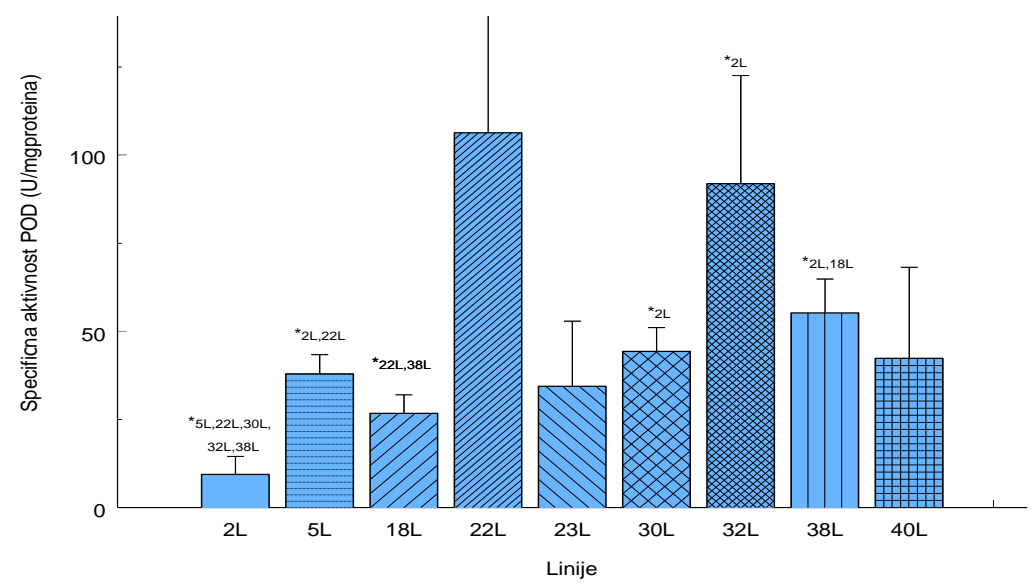

Figure 3.Enzyme activity of peroxidases expressed as specific activity (U/mg of proteins) in the needles of various Austrian pine lines

Figure 3 shows the results of specific enzyme activity of peroxidases in the needles of austrian pine. The lowest value was measured in the line 2 , and it amounted to $9.5 \mathrm{u} / \mathrm{mg}$ of proteins, and the highest in the line 22 , which amounted to $110 \mathrm{u} / \mathrm{mg}$ of proteins. To the greatest extent, statistically significant difference was demonstrated between the lines 2 and 22 .

The results of studies showed that the change in the concentration of total proteins and activities of peroxidase enzyme in the needles of austrian pine lines, wherefrom the seed orchard of this species was established on jelova gora mountain near užice, significantly differed (figures 2 and 3). Proteins have various expression level in the individual austrian pine lines, while at the same time peroxidase enzyme shows different activity which can be considered to be under direct genetic control, having in mind that the influence of external factor was minimized due to relatively small seed orchard area. Various activities of enzymes and proteins which have been recorded show that genetic variation of analyzed austrian pine half-sib lines is highly significant for the further directed use of the genetic potential of this species. Other authors, e.g. Leinemann, demonstrated that the composition of isoenzymes of other enzymes, such as glucose-6-phosphate dehydrogenase (g-6-pdh) or isocitrate dehydrogenase (idh) had special importance during the separation of various subspecies of prunus spinosa (leinemann, 2000). This method is currently successfully applied for reliable determination of genetic base in species and subspecies variability of trees.

Results of the analyses performed with spruce needles, radotić et al. 2000, showed that the occurrence of new isoenzymes of peroxidases in spruce needles was an indicator of stress caused by heavy metals (cd, ni, cu). This poses new questions for future researches in the sense - are the other enzymes reliable 
indicators of divergences inside species and could some enzymes of antioxidant defense be reliably used in order to monitor environmental pollution?

\section{CONCLUSIONS}

Results of the performed analyses show the presence of pronounced variability in the concentration of total proteins, content of heavy metals and activities of peroxidase enzyme in two-year-old needles of analyzed Austrian pine half-sib lines. Concentration of total proteins and activities of peroxidase enzyme are significantly different in various Austrian pine half-sib lines (Figures 2 and 3) while the proteins have various level of expression in individual lines.

In addition, peroxidase enzyme shows different activity which depends on genetic constitution of the trees from analyzed half-sib lines, because based on the seed orchard size and the planting pattern, it can be assumed that the effect of external factors is reduced to minimum. Peroxidases present as soluble in apoplast, or covalently bound to cell wall, play an important role in lignification, suberization, healing injuries, defense against pathogens and airborne pollutants.

\section{REFERENCES}

Abeles F. B. (1986): Plant chemiluminescence. Ann. Rev. Plant Physiol. 37, 49-72 Helliwell B. (1981): The structure and function of chloroplasts in green leaf cells. Chloroplast metabolism. Clarendon Press. Oxford

Brisson, L. F., Tenhaken R. and Lamb C. J. (1994): Function of oxidative cross-linking of cell wall structural proteins in plant disease resistance. Plant cell 6, 1703-1712

Gaspar T., Penel C., Hugege D., Greppin H. (1991): Biochemical, Molecular and Physiological Aspects of Plant Peroxidases, University M. Curie-Sklodowski, Lubin, Poland, and University of Geneva, Switzerland, 249-280

Hippeli S. \& Elstner E. E. (1996): Mechanisms of oxigen activation during plant stress: biochemical effects of air pollutants. J. Plant Physiol. 48, 249-257

Isajev, V.,Sijacic-Nikolic M. and Mataruga M.(1999): Conservation. Tasting and Utilisation of Tree Species Gene Pool in Specialised Plantations. Proceeding of the 4th International Conference on The Development Of Wood Science, Wood Technology and Forestry.Missenden Abbey. p.225-235.

Leinemann L. (2000): Inheritance analysis of isozyme phenotypes in tetraploid species using single plant progenies. An example in black thorn (Prunus spinosa L.). Forest Genetics 7(3), 205-209,

Mataruga M., Isajev V., Šijačić-Nikolić M. (2001): The possibility of testing and preserving biodiversity of black pine (Pinus nigra Arn.) in seed orchard metapopulation structure.Proceedings of the International Conference:FOREST RESEARCH:A Challenge for an Integrated European Approach.Thessaloniki-Greece. Volume II. 595-598.

Mataruga, M., Isajev, V.(1998): Mogućnost testiranja i očuvanja biodiverziteta crnog bora u specijalizovanim kulturama. Zaštita prirode br 50. Beograd. Str. 63-71

Polle A. and Chakrabarti K. (1994): Effects of manganese deficiency on soluble apoplastic peroxidase activities and lignin content in needles of Norway spruce (Picea abies). Tree Physiol. 14,1191-1200 
Rabe R. and Kreeb K. H. (1979): Enzyme activaties and chlorophyll and protein content in plants as indicators of air pollution. Environ. Pollut. 19, 119-136

Radotić K., Dučić T., Mutavdžić D. (2000): Changes in peroxidase activity and isoenzymes in spruce needles after exposure to different concentrations of cadmium. Environ. Exp. Bot. 44, 105-113 